\title{
SETTLEMENT OPEN SPACE DEVELOPMENT BY APPROACH WSUD METHOD IN MANADO CITY
}

\author{
Fela Warouw ${ }^{1 *}$, Veronica Kumurur ${ }^{1}$, Ingerid Moniaga ${ }^{1}$ \\ ${ }^{1}$ Department of Architecture, Sam Ratulangi University, Kampus Bahu, Manado 95115, INDONESIA \\ *Corresponding author; Email: felawarouw@gmail.com
}

\begin{abstract}
Nowadays, the quality of green open space in urban settlements is gradually decreasing because of land use changes as well as new building construction. Moreover, urban community is often facing risk of river flooding and rainwater puddles during the rainy season. The purpose of this research is developing an urban open space network with function to managing rain water in settlement areas in Manado city. The WSUD planning principles is analysis as research variable and open space areas are defined into four type's namely public zone, semipublic zone, semi private zone and private zone. This open space zones is considering into two main aspect, first the user of space (private or public) and next the decision maker (individual, groups, local government). The planning concept for urban settlement areas sensitive to water can be achieved by approaching three development types: open space network, buildings layout and streetscape.
\end{abstract}

Keywords: Urban settlement; open space; WSUD; climate change; Manado City.

\section{INTRODUCTION}

As a result of the impact of global climate change, Manado is facing increasing risks of flooding during the rainy season. A phenomenon occurs in urban settlements development is gradually and massive, decreasing of green open space quantities either in micro scale on building plots nor the macro scale form of conversion of agricultural land into residential areas. Most of existing urban housing is not concern for maintaining the private green space which is disappearing due to life style changes and new building function. After the extraordinary flooding in 2014, BPBD province of SULUT introducing the flood control strategy for Manado city. The mitigation policies implemented into several development program and activities, namely: infiltration wells and biopori, rehabilitation of drainage system, controlling rainwater puddle (basin retention, polder, pump), arrangement of buildings and healthy living environments (flats, green open spaces, garbage disposal system) and more.

The effort for adapting and mitigating the climate change is the goal of Green City Development Program (Program Pengembangan Kota Hijau $\mathrm{P} 2 \mathrm{KH}$ ) which was introduced in 2011. The main target of $\mathrm{P} 2 \mathrm{KH}$ is the increase area of urban green open space qualified as much as $30 \%$ of the area of the city. Mitigation action in the Directorate General of human settlement is development of green buildings and green open space facilities or green infrastructure. While the aim in the adaptation strategy is the provision of urban drainage systems that is environmentally friendly (eco-drain and independent drainage) and implementation of technology of drainage system to anticipate the impact of changes in extreme rainfall such as absorption wells, perforated drain, retention ponds and rainwater harvesting under a green open space. To support the local and central government, this study aims to integrate sustainable drainage systems on the means of green open space in city's living environment. This paper will discuss the strategy for the development facilities of settlement's green open space in Manado as part of the management system of rainwater. One of the approaches used is the concept of sustainable management of water called Water Sensitive Urban Design in urban settlement area in Manado.

\section{Water Sensitive Urban Design Concept}

Fundamental to the philosophy of WSUD is integrated adoption of appropriate Best Planning Practices (BPPs) and Best Management Practices (BMPs). A BPP refers to site assessment, planning and design component of WSUD. A BPP's is defined as the best practical planning approach for achieving or contributing to defined management objective in an urban situation. This included site assessment of physical and natural attributes of the site and capability assessment. Using this as a basis the next step is integrating water and related environmental management objectives into site planning and design. BPPs may be implemented at the strategic level or at the design level. A number of planning and design tools for WSUD project based on BPP principles have been developed which relate to the following: Public 
Open Space Networks, Housing Layout, Road Layout and Streetscape. BMP refers to the structural and non-structural elements of a design that perform the prevention, collection, treatment, conveyance, storage and reuse function of WSUD. BMPs have been grouped into two generic assemblages, these being portable water demand reduction techniques and storm water management techniques. The objectives of Water Sensitive Urban Design are (CSIRO, Urban Storm water, 2006):

1. Protection and enhancement of natural water systems in urban development,

2. Integration of storm water treatment into the landscape by incorporating multiple use corridors that maximize the visual and recreational amenity of developments,

3. Protection of water quality draining from urban developments,

4. Reduction of runoff and peak flows from urban developments by employing local detention measures and minimizing impervious areas, and

5. Adding value while minimizing drainage infrastructure development cost.

WSUD methods can be grouped according to their primary function: water use, treatment, detention and infiltration, conveyance and evapotranspiration. Water use has practical advantages in that it reduces service demand and saves energy, resources and cost over time. Storm water treatment is necessary before use in domestic water services or before infiltration into the ground if runoff does not meet quality standards specified by applicable guidelines. Detention and infiltration systems temporarily store water and gradually infiltrate it into the ground or convey it to be infiltrated elsewhere. Conveyance such as canals is an alternative to underground sewers. Canals can convey storm water from impervious surfaces such as rooftops and streets into underground sewer systems or decentralize management systems. Evapotranspiration is an integral and vital component of the water cycle. Plants consume water and transpire, and water bodies exposed to heat and sun evaporate. This process has effect on temperature, humidity and precipitation. The next the selection of WSUD method can be considered according to the scale and type of development that residential scale, medium density, high-rise buildings, commercial and industrial areas, residential subdivisions and urban retrofit.

\section{Green Open Space and Watershed Condition in Manado City}

Moniaga (2015) states that the planning of green open space and green open space network system that serves as a green infrastructure should be reflected in the structure and patterns of utilization of urban space as a part of local regulations on spatial plan. Network infrastructure green open space as Green Cities should be distributed to all districts of the city of Manado in the form of area and lines (links), in order to function optimally in creating a balance of urban ecosystem. To realize the $30 \%$ percent of green open space need planning based on the potential of nature, the seriousness of the local government, and community participation. Spatial planning of cities and regions need to be evident, which areas are to be preserved, which areas are conserved, and which areas should be built. Then arrange a green and blue open space plan. Viewed from the development strategy means of open green space settlements in Manado as part of the rainwater management system, open space in several districts in the city of Manado is still lacking. Based on the results of research on green open space conducted by Erwin concluded that the actual land in Manado City RTH identified of \pm 12549.44 ha while those not vegetated area of \pm 3967.54 ha. District of Sario is an area that has the least green space area, followed by the District Wenang and Sub-district Tuminting. Based on these factors the number of people, vehicles, livestock and hospitality, the minimal requirement of green space in the city of Manado is an area of 892 ha so that they meet the requirements. District with highest RTH is Mapanget, while the district that has the lowest RTH is Wenang, Sario, and Tuminting.

Based on the main concepts WSUD in case provides protection and improvement of natural water systems in the urban environment and protection of the quality of the water flowing in the urban environment, Manado City is still far from eligibility as seen from the water quality of the river that flows through the city of Manado. The river is one of the resources that are flowing (flowing resource), so that the use in the upstream can reduce water quality, pollution and social costs for preservation. River water pollution is largely determined by the activities and benefits of water resources by humans who are in those waters area. Research conducted by Lensun et al (2013), BOD and the turbidity of Tondano river water in the Ternate village Tondano in Manado City has passed the Class II Water Quality Standard PP 82 of 2001 and categorized as polluted, where the main cause of water pollution in this area is domestic waste, fish feed and industrial waste. This is supported by research Taringan et al (2013) which investigated the the quality of the waters in the city of Manado, where in the research, Bailang River are in the category of "eligible for all classes" based on the water quality parameters $\left(\mathrm{BOD}_{5}\right.$, phosphate dan nitrate); River 
Maasing to be in the category of "not feasible for all classes" based on the parameters $\mathrm{BOD}_{5}$ and "unfit for class" I, II and III based on the parameters of phosphate; for Tondano River is in the category "unfit for class" I, II, based on the parameters $\mathrm{BOD}_{5}$ and phosphate $\left(\mathrm{PO}_{4}\right)$.

Research on the river in the city of Manado also conducted by Tarima, et al (2015) in which the study concluded that the Sario river water quality in accordance with the water quality standard threshold under PP 82/2001 only on the upstream side to the middle of the river before entering the city of Manado, while the downstream area Sario river has been polluted related activity is indicated by the community with the concentration of BOD, COD and DO poor and not in accordance with the water quality standard threshold under PP 82/2001. Besides the problem of water pollution of the river, the river in the city of Manado often catastrophic floods that occur almost every year and one of the biggest was in 2014. In study research of Sompie and Mandagi (2012) the problem of flooding is likely to increase from year to year primarily due to changes in the nature of flooding and the rapid development of human activities in the flood plain. Results showed that the risk factors for people's habits have the greatest value of $52 \%$, next factors is catchment area with a value of $17 \%$, the management of Watershed with a value of $17 \%$, the runoff factor with a value of $13 \%$, and the silting up the river with a value of $4 \%$.

\section{Regulation and Policies of Open Space and Storm Water Management}

General provisions of zoning regulations for the city green open space referred to Manado City Spatial Plan (RTRW Manado 2014-2034) is explain that: a. Green Open Space zone which is a local green space protection area in the form of green open space river banks, green open space securing raw water sources / springs, and recreation, and are prohibited from activities that lead to the undermining of green open space; $b$. the proportion of green space in urban areas amounted to at least 30 (thirty) percent of which consists of 20 (twenty) percent of public green open space and ten (10) percent of private green open space; and c. housing plot development is required to provide RTH 20 (twenty) percent of the plot that will be handed over to the Municipality as an asset of the City Government.

Storm water management system in Indonesia has started described in various policies (Tabel 1). In the policy of the rain water management facilities in buildings and a plot (Permen PU No.11/2014), storm water management is an effort and activities to maintain the natural hydrological conditions by maximizing the utilization of rainwater, infiltration of rainwater and temporarily saves rainwater to reduce the flood discharge by optimization the utilization of natural elements and utilization of artificial elements. There are two benefits that can be gained in the management of rainwater, namely:

1). Water resources. Water is clean and free of pollutants, recharge groundwater, reduce the use of water from the taps and wells drilled/ground water, protection of water resources);

2). Environmental and social life. Reduce storm water run-off, prevent land subsidence, lowering the temperature of urban areas, the human form of mitigation and adaptation to climate change, improving energy efficiency, the benefits of community/urban aesthetic/recreation and natural habitat for wildlife.

Facility management is a building that is operated for the collection and utilization, infiltration and detention of rain water. Types of facilities include: rain water harvesting facilities, retention and detention facilities. Rainwater harvesting facility can be basin, pools, water tanks, reservoirs etc. The form of facility retention can be infiltration wells, infiltration pond, biopori holes and other similar technology which serves to collect and absorb rainwater into the ground. Form of facility detention can be basin/ reservoir/retention ponds, vertical gardens (green facades and living wall), a rooftop garden and other similar technology that serves to collect rainwater temporarily so as not to overflow before being discharged into the urban drainage (Permen PU No.12/2014) where the government regulates the role of public and private for the supply of recharge wells, reservoir pond, tamping pool, an appropriate retention characteristics of the region.

Both of these policies can be used to establish and optimize the ecological function of the green open space and non-green open space. Landscaped green space and community garden (Permen PU No.05/2008) among other things regulates the microclimate that the air circulation system and water can be naturally last smoothly; absorption of rainwater; and absorbent media pollutants of air, water and soil. The non-green open space (Permen PU No.12/2009) is part of the circulatory system of air and water environmental scale, regions and cities; as well as the absorption of rain water by the utility components such as catchment wells. If the of green open space yard to work optimally, the performance indicators of green residential building society can be achieved (Permen PUPR no.02/2015). The Climate Kampong Program (Permen LH No.19/2012) has purpose of for encouraging the community to increase adaptive capacity to climate change impacts and 
reduction in greenhouse gas emissions. Climate change adaptation efforts for control purposes droughts, floods and landslides conducted through storm water management, among others: 1). Rainwater harvesting such as rainwater and ponds in scale individual and communal; 2). Biopori a hole of water infiltration, infiltration wells, building of waterfall drain/ BTA, rorak and drain water management/ SPA; 3). Provision of flood control infrastructure such as dams, reservoirs, dikes etc.

\section{METHODOLOGY}

This exploratory research method focusing on WSUD concept for developing the research variable then continue to field observations to find out the characteristic of local open spaces. Location sample determined to the district area that suffers flooding and certain area with puddles, riverbanks area and/or small streams area. Random sampling has to be applied to the private buildings (residential and nonresidential function), public facilities (religious buildings, schools, district office and park), lane highway, and drainage lines (naturally or artificially). Policy studies that related to research's focus such as rain water harvesting system, green open space and another open space, river's border area. Observation data's that have been acquired then will be analysis with frequency distribution statistic method to determine urban open space typology. Observation data's then will be proceed with spatial analysis to find out buildings density pattern and open space pattern (public and private). Afterward WSUD selection methods determined by open space typology, so WSUD Planning concept can be specified, the planning concept consist of open space network, building layout and streetscape. The case study of WSUD planning concept is located on the Ranotana at Wanea District, with the consideration that the areas has the problem of flooding if rainfall debit large, but the value of rest there has a lot of potential for development green open space by WSUD based methods. Ranotana an urban village environment that commonly experienced floods and puddles, located on the banks of the river and had small stream.

Table 1. Rain Water Management Policies in Indonesia

\begin{tabular}{|c|c|c|c|c|c|}
\hline & $\begin{array}{c}\text { Climate Village } \\
\text { Program }\end{array}$ & $\begin{array}{r}\text { Urban d } \\
\text { syst }\end{array}$ & $\begin{array}{l}\text { Management } \\
\text { Buildings }\end{array}$ & $\begin{array}{l}\text { Green open space and } \\
\text { Non-green open space } \\
\text { in city }\end{array}$ & $\begin{array}{l}\text { Green building and } \\
\text { Greenship Building } \\
\text { Council Indonesia }\end{array}$ \\
\hline & $\begin{array}{l}\text { Rain of water } \\
\text { harvesting in } \\
\text { individual and } \\
\text { communal scale } \\
\text { Biopori water } \\
\text { infiltration holes, } \\
\text { infiltration wells etc. } \\
\text { Flood Control Facility } \\
\text { such as retention } \\
\text { ponds / retention } \\
\text { basin, wet pond, } \\
\text { detention basin / dry } \\
\text { pond, retarding basin }\end{array}$ & $\begin{array}{l}\text { Reservoir pool, } \\
\text { Infiltration Wells } \\
\text { and Retention pond } \\
\text { provided by public } \\
\text { and private }\end{array}$ & $\begin{array}{l}\text { helter Facility } \\
\text {, pools, water } \\
\text { oirs etc. } \\
\text { ntion such } \\
\text { vells, } \\
\text { ond, biopori } \\
\text { her } \\
\text { acility in the } \\
\text { eservoir / } \\
\text { nd, vertical } \\
\text { en facade), a } \\
\text { other }\end{array}$ & $\begin{array}{l}\text { a. Non Green Open } \\
\text { Space such as } \\
\text { infiltration wells as } \\
\text { drainage networks in } \\
\text { yard of the house / } \\
\text { dwelling } \\
\text { b. Green open space } \\
\text { such as vegetation } \\
\text { garden courtyard } \\
\text { with shade trees, } \\
\text { shrubs, bushes and } \\
\text { grass plots customized } \\
\text { by home area. }\end{array}$ & $\begin{array}{l}\text { a. Reduction of water } \\
\text { consumption average } \\
\text { of } 10 \% \text {, by } \\
\text { optimization of green } \\
\text { open space yard } \\
\text { function } \\
\text { b. } \\
\text { c. Water Conservation } \\
\text { category on indicators } \\
\text { of alternative water } \\
\text { sources, the efficiency } \\
\text { of water use } \\
\text { landscaping, rainwater } \\
\text { harvesting. }\end{array}$ \\
\hline
\end{tabular}
Men PUPR No.02/2015; GBCI 2013

Tabel 2. Characteristics of Observed Building

\begin{tabular}{lcccc}
\hline \multirow{2}{*}{ Urban village } & Total Sample (Unit) & \multicolumn{3}{c}{ Building Function } \\
\cline { 3 - 5 } & & $\begin{array}{c}\text { Private Housing, Mixed } \\
\text { Use }\end{array}$ & $\begin{array}{c}\text { Private Commercial, } \\
\text { Offices }\end{array}$ & $\begin{array}{c}\text { Public and Social } \\
\text { Facilities }\end{array}$ \\
\hline Sario Utara & 20 & 0 & 19 & 1 \\
Tanjung Batu & 39 & 11 & 20 & 8 \\
Pakowa & 20 & 16 & 2 & 2 \\
Ranotana & 60 & 42 & 14 & 4 \\
Ranotana Weru & 35 & 20 & 0 & 3 \\
Sario & 28 & 20 & 5 & 5 \\
Sario Kota Baru & 35 & 22 & 6 & 38 \\
\hline TOTAL & 237 & 131 & $29 \%$ & $16 \%$ \\
\hline \multicolumn{2}{r}{ Percentage } & $55 \%$ & &
\end{tabular}




\section{RESULTS AND DISCUSSION}

\section{Characteristics of Private Open Space in Manado City: Typology and Quality}

The typology of green open space in the settlement area of Manado City such as open space multifunctional (sports fields, etc) as Tikala Field, Stadium Klabat, Koni Fields, Bantik Fields; landscaped residential functions, commercial functions as well as public facilities; cemetery and the street green line. While the potential of blue open space on river banks and coastal border are already planned in Manado City RTRW 2014-2034 year. In a study on the evaluation of the quality of private open space in 5 villages in the city of Manado (Fela, 2015) found several conditions such as:
1. The private green open space in residential buildings of the park yard as much as $80.77 \%$ of the 104 samples.

2. Private non-green open space in the commercial and office building are mostly serves as a parking area and/or circulation areas as much as $80.30 \%$ of the 132 samples.

3. Green open space vegetation types such as plant on the ground with a variety of trees, bushes, shrubs, grasses as much as $49.41 \%$ of the total 253 samples.

4. Green open space vegetation types such as plants in pots with a variation of small and medium-size pot as much as $52.57 \%$ of the total 253 samples.

5. Type non-green open space surface covering material is concrete (46.54\%); asphalt (20.38\%); paving stone $(11.92 \%)$ of the total 253 samples.

Tabel 3. Characteristics of Private Open Space

\begin{tabular}{lccccc}
\hline \multirow{2}{*}{ Urban village } & \multirow{2}{*}{ Total Sample } & \multicolumn{2}{c}{ Green Open Space } & \multicolumn{2}{c}{ Non-Green Open Space } \\
\cline { 3 - 6 } & & Available & Not available & Available & Not available \\
\hline Sario Utara & 20 & 20 & 0 & 7 & 13 \\
Tanjung Batu & 39 & 34 & 5 & 21 & 18 \\
Pakowa & 20 & 15 & 5 & 13 & 7 \\
Ranotana & 60 & 39 & 21 & 39 & 21 \\
Ranotana Weru & 35 & 14 & 1 & 10 & 5 \\
Sario & 28 & 15 & 13 & 14 & 14 \\
Sario Kota Baru & 35 & 21 & 14 & 23 & 12 \\
\hline TOTAL & 237 & 158 & 59 & $53.59 \%$ & $37.97 \%$ \\
\hline \multicolumn{2}{l}{ Percentage } & & $66.67 \%$ & $24.89 \%$ & \\
\hline
\end{tabular}

Source: Research Observation Analysis on 2016

Tabel 4. Typologi of Green Open Space for Private Housing

\begin{tabular}{lcccccc}
\hline \multirow{2}{*}{ Urban Village } & \multirow{2}{*}{ Total Sample } & \multicolumn{2}{c}{ Vegetation on Pot } & \multicolumn{2}{c}{ Vegetation on the Ground } \\
\cline { 3 - 7 } & & Available & Not available & Trees & Grass, Shrub & Not Available \\
\hline Sario Utara & 0 & 0 & 0 & 0 & 0 & 0 \\
Tanjung Batu & 11 & 5 & 6 & 7 & 3 & 1 \\
Pakowa & 16 & 6 & 10 & 6 & 5 & 5 \\
Ranotana & 42 & 40 & 2 & 23 & 4 & 15 \\
Ranotana Weru & 20 & 11 & 9 & 12 & 0 & 8 \\
Sario & 20 & 8 & 12 & 5 & 3 & 2 \\
Sario Kota Baru & 22 & 13 & 9 & 13 & 6 & 43 \\
\hline TOTAL & 131 & 83 & 48 & 66 & 21 & 2 \\
\hline
\end{tabular}

Source: Research Observation Analysis on 2016

Tabel 5. Typologi of Non Green Open Space for Private Housing

\begin{tabular}{|c|c|c|c|c|c|c|}
\hline \multirow[b]{2}{*}{ Urban Village } & \multirow[b]{2}{*}{$\begin{array}{c}\text { Total } \\
\text { Sample }\end{array}$} & \multicolumn{2}{|c|}{ Grey Open Space } & \multicolumn{2}{|c|}{ Open Space Function } & \multirow[b]{2}{*}{ Surface Material } \\
\hline & & Available & Not available & $\begin{array}{c}\text { Parking, } \\
\text { Circulation }\end{array}$ & Open Park & \\
\hline Sario Utara & 0 & 0 & 0 & 0 & 0 & - \\
\hline Tanjung Batu & 11 & 8 & 3 & 8 & 0 & Asphalt, Concrete, Paved, Ground \\
\hline Pakowa & 16 & 13 & 3 & 13 & 0 & Concrete, Paved, Ground \\
\hline Ranotana & 42 & 28 & 14 & 17 & 11 & Concrete, Paved, Ground \\
\hline Ranotana Weru & 20 & 16 & 4 & 14 & 2 & Concrete, Paved, Ground \\
\hline Sario & 20 & 12 & 8 & 12 & 0 & Concrete, Paved \\
\hline Sario Kota Baru & 22 & 15 & 7 & 15 & 0 & Concrete, Paved \\
\hline TOTAL & 131 & 92 & 39 & 79 & 13 & \\
\hline
\end{tabular}

Source: Research Observation Analysis on 2016 

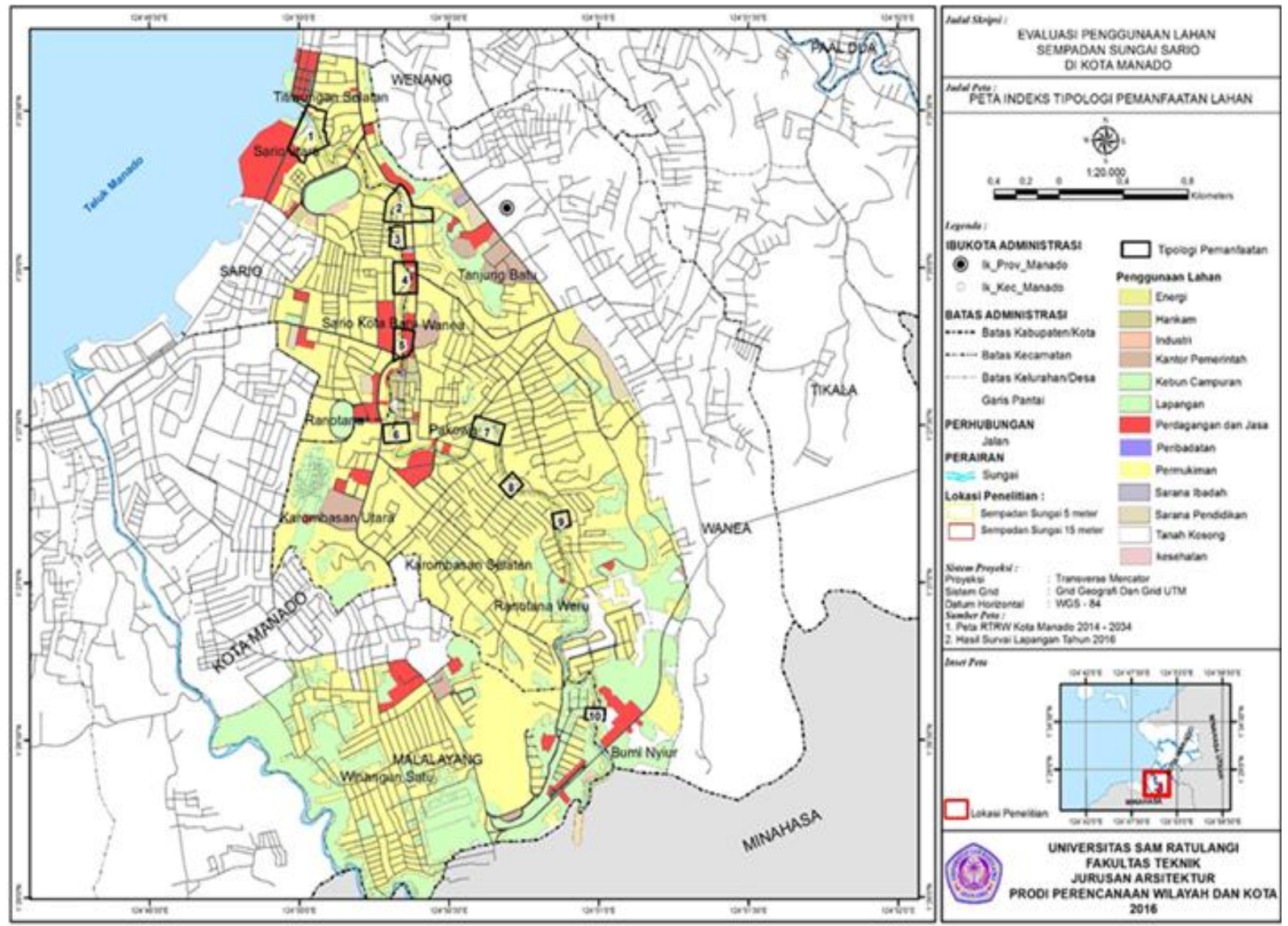

Fig. 1. Typology of Riparian Landuse in Sario Watershed Areas (Source: Labora, 2016)

Tabel 6. Typology of Riparian Areas in Sario Watershed Zone

\begin{tabular}{lccccr}
\hline \multirow{2}{*}{ Urban Village } & Total Area & \multicolumn{2}{c}{ Riparian 5 m } & \multicolumn{2}{c}{ Riparian 15 m } \\
\cline { 3 - 6 } & $(\mathrm{Ha})$ & Area $(\mathrm{m} 2)$ & Building (unit) & Area $(\mathrm{m} 2)$ & Building (unit) \\
\hline Sario Utara & 56.70 & 5972,47 & 71 & 18090,31 & 121 \\
Tanjung Batu & 20.15 & 4976,97 & 35 & 13511,44 & 72 \\
Pakowa & 25.81 & 6874.75 & 64 & 21840,26 & 90 \\
Ranotana & 32.31 & 1905,17 & 22 & 5815,12 & 30 \\
Ranotana Weru & 32.24 & 10156,32 & 62 & 30995,39 & 104 \\
Wanea * & 41.14 & 3964,16 & 31 & 12130,52 & 46 \\
Sario Kota Baru & 62.31 & 3853,68 & 48 & 11856,91 & 80 \\
\hline
\end{tabular}

Source: Labora, Undergraduate Research Thesis on 2016

Tabel 7. Typology of Riparian Land Use in Sario Watershed Zone

\begin{tabular}{lrrrrr}
\hline \multirow{2}{*}{ Urban Village } & \multicolumn{5}{c}{ Riparian 15 m(m2) } \\
\cline { 2 - 5 } & Housing & $\begin{array}{c}\text { Commercial, } \\
\text { Office }\end{array}$ & Farming & Vacant Land & $\begin{array}{c}\text { Public, Social, Industrial } \\
\text { Facilities }\end{array}$ \\
\hline Sario Utara & 13654,13 & 548,47 & - & 1234,68 & 2653,02 \\
Tanjung Batu & 9208,08 & 1826,87 & 466,69 & 3533,21 & - \\
Pakowa & 14590,82 & 1075,54 & 4227,78 & 1946,11 & - \\
Ranotana & 1996,43 & 3818,69 & - & - & - \\
Ranotana Weru & 20339,53 & - & 8089,77 & 2504,63 & 61,47 \\
Wanea ) & 1692,95 & 5748,89 & - & - & 4688,68 \\
Sario Kota Baru & 9484,49 & 813,75 & - & 760,22 & 798,45 \\
\hline
\end{tabular}

Source: Labora, Undergraduate Research Thesis on 2016 
6. Based on vegetation density index, the quality of the ecological functions of green space in each zone classified as moderate and low. While the assessment on the quality of the ecological functions non-green open space according to land surface conditions included in the category of 75$100 \%$ of the surface is not water resistant, surface flow (run-off) of $55 \%$, only $15 \%$ the ability of infiltration and evapotranspiration $30 \%$.

\section{Characteristics of Building Density in Sario River Watershed Area}

Analysis of land use type at riparian zone of Sario river has shown that residential areas is reached the highest number at $66243,93 \mathrm{~m} 2$. According to Manado city landuse regulation (RTRW 2014-2034), this riparian zone have wide at least 15 meters and the research shown that $31 \%$ of land use is un built area while the built up areas is cover $69 \%$ of total riparian zones. The research also reveal the physical condition of built up areas such as embankment walls and ground floor building foundation and walls. The vegetation and natural element of river space is disappear, instead of city drainage outlet with trash and garbage or grey water pipe are often appears along the river stream.

\section{Spatial Analysis of Open Space at Ranotana village}

Spatial analysis on the location of the study sample was divided into six zones using spatial ArcGIS mapping techniques as shown in the figure 2. Then, open space analysis is divided according to ownership of building or facility, first is private and individual type (figure 3) and second is public and government type (figure 4).

Based on the calculation analysis of private open space on the location of the study sample, private building ownership open space has a total area of 24.2 hectares while settlement type open space has the greatest number of $11.4 \mathrm{Ha}$ (table. 9). As for calculation analysis of public open space with total of space 8.72 Ha divided on public green open space, public non green open space and blue open space area (figure 4).

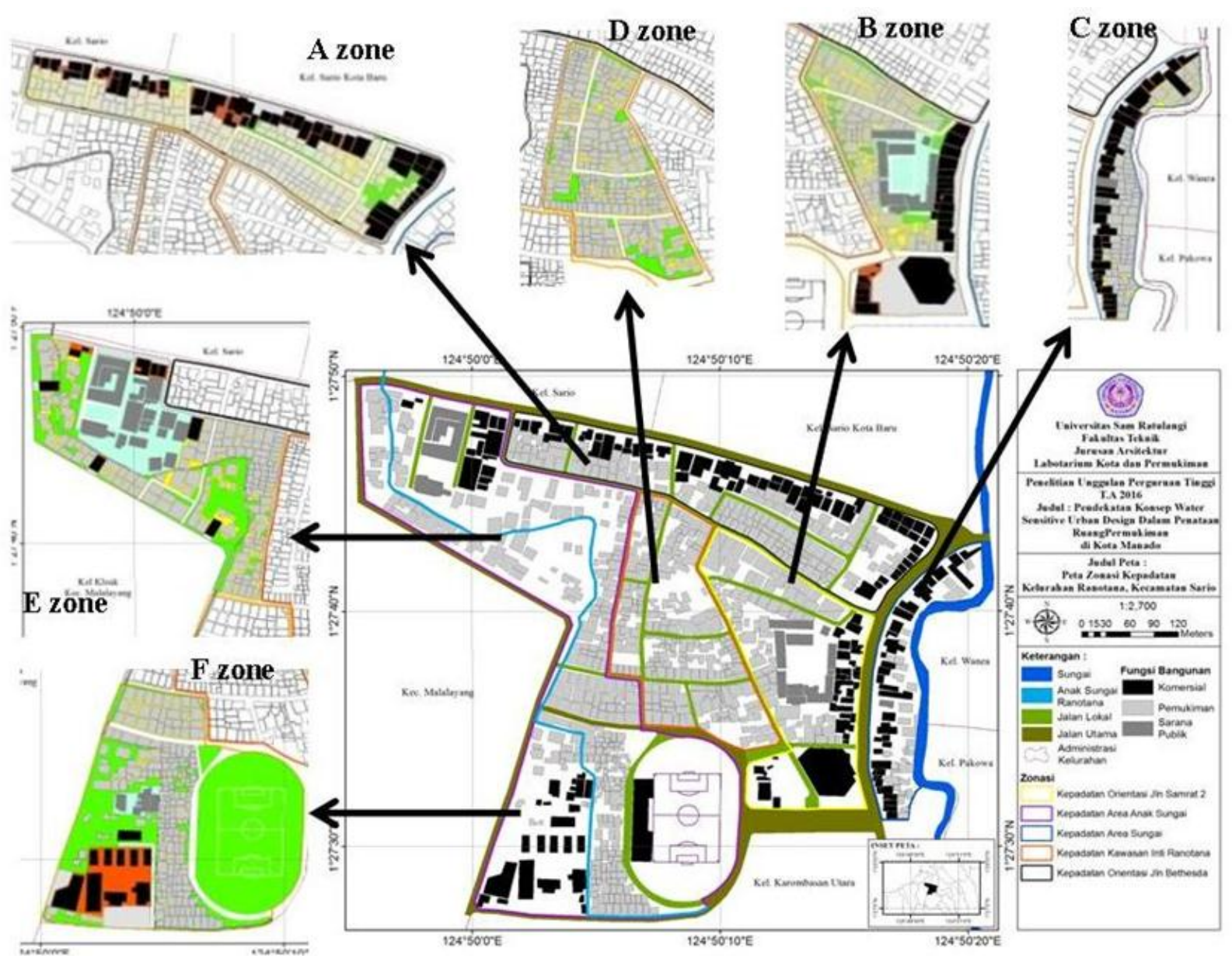

Fig. 2. Map of Land use zone in Ranotana 


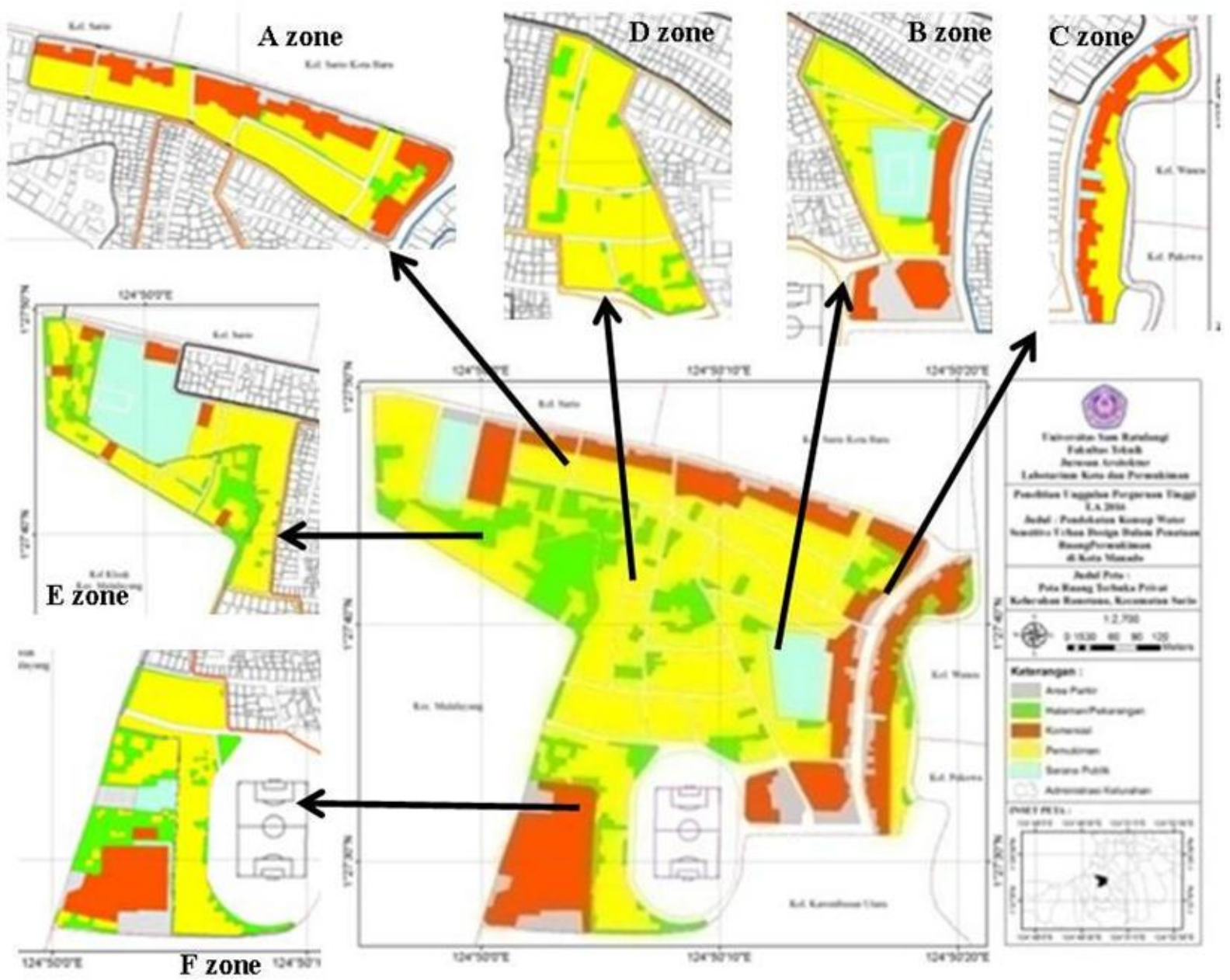

Fig. 3. Private Open Space Analysis Map

Table 8. Building Density and Open Space Area in Ranotana Village

\begin{tabular}{lccc}
\hline \multicolumn{1}{c}{ Zona } & $\begin{array}{c}\text { Total Areas } \\
(\mathrm{Ha})\end{array}$ & $\begin{array}{c}\text { Developed Land } \\
(\mathrm{Ha})\end{array}$ & $\begin{array}{c}\text { Undeveloped Land } \\
(\mathrm{Ha})\end{array}$ \\
\hline A. Building Areas Orientation to Bethesda Street & 4.5 & 2.3 & 2.2 \\
B. Building Areas Orientation to Samratulangi 2 Street & 4.7 & 2.8 & 1.9 \\
C. Building Areas at Riparian Sario Watershed & 2 & 0.9 & 1.1 \\
D. Building Areas Orientation to Local Street & 3.8 & 2.1 & 1.7 \\
E, F. Building Areas Orientation to Ranotana Creeks & 14 & 5 & 9 \\
\hline Total & 29 & 13.1 & 15.9 \\
\hline
\end{tabular}

Table 9. Private Open Space Zone Analysis

\begin{tabular}{ccccrr}
\hline Zona & Parking Area $(\mathrm{m} 2)$ & $\begin{array}{c}\text { Settlement Area } \\
\left(\mathrm{m}^{2}\right)\end{array}$ & $\begin{array}{c}\text { Green Yard } \\
\left(\mathrm{m}^{2}\right)\end{array}$ & $\begin{array}{r}\text { Commercial Facility } \\
\left(\mathrm{m}^{2}\right)\end{array}$ & $\begin{array}{r}\text { Public Facility } \\
\left(\mathrm{m}^{2}\right)\end{array}$ \\
\hline A & 4377 & 24933 & 1889 & 14205 & 0 \\
B & 6013 & 16813 & 2157 & 9178 & 8488 \\
C & 2431 & 9662 & 4287 & 486 & 0 \\
D & 31907 & 4263 & 0 & 0 & 0 \\
E & 1615 & 28388 & 9543 & 3066 & 17136 \\
F & 3639 & 21956 & 10540 & 8739 & 1667 \\
\hline Total & $1.7(\mathrm{Ha})$ & $11.4(\mathrm{Ha})$ & $4.0(\mathrm{Ha})$ & $5.7(\mathrm{Ha})$ & $1.4(\mathrm{Ha})$ \\
\hline
\end{tabular}




\begin{tabular}{ll}
\hline Open Space Type & Ha \\
\hline 1. Primary road & 3.3 \\
2. Local road & 1.8 \\
3. Sario River & 0.4 \\
4. Small River & 0.3 \\
5. Klabat Sport field & 2.5 \\
6. School field & 0.2 \\
7. PLN office field & 0.1 \\
8. STAKN field & 0.06 \\
9. Samrat vocal point & 0.01 \\
$\quad$ park & \\
10. City Park beside Grand & 0.03 \\
$\quad$ Puri Hotel & \\
11. Median Park Grand & 0.02 \\
$\quad$ Puri Hotel & $\mathbf{8 . 7 2}$ \\
\hline TOTAL &
\end{tabular}

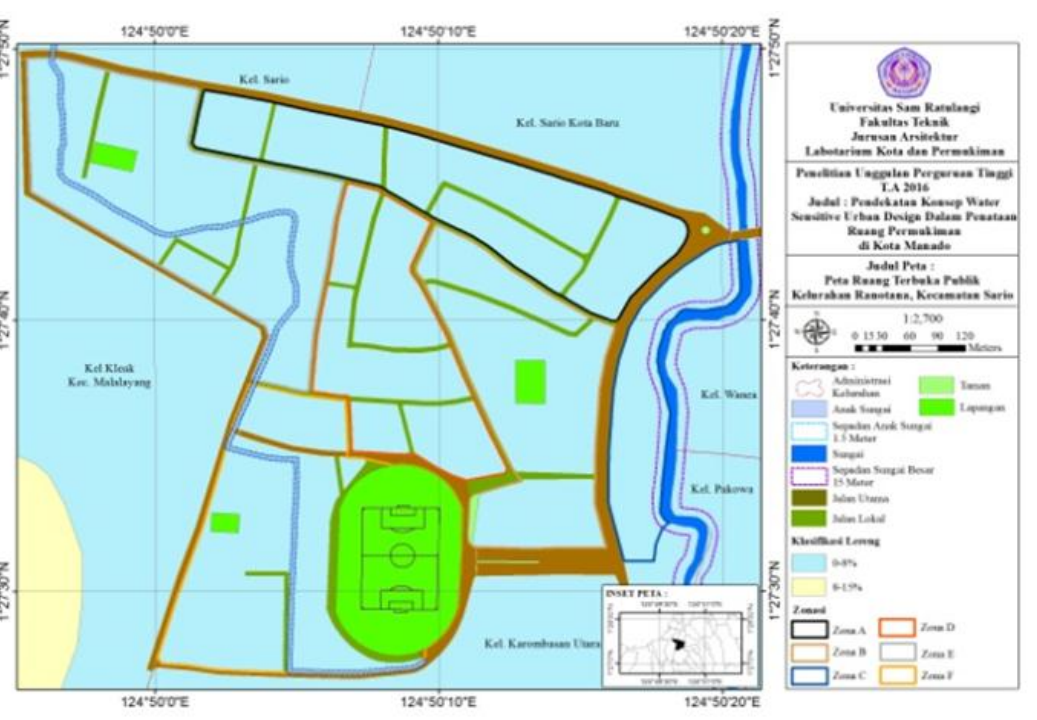

Fig. 4. Public Open Space Analysis Map and Table

Table 10. Open Space Network for Urban Open Space in Manado

\begin{tabular}{|c|c|c|c|c|}
\hline Zone & User/decision maker & $\begin{array}{l}\text { Typology of Open Space } \\
\text { (existing) }\end{array}$ & $\begin{array}{l}\text { WSUD Planning } \\
\text { Type } \\
\end{array}$ & $\begin{array}{l}\text { WSUD Method } \\
\text { Development }\end{array}$ \\
\hline Public & Public/Local Government & $\begin{array}{l}\text { Garden Village (if any), Fields, } \\
\text { Border River, Pedestrian street, } \\
\text { Median and Side streets. }\end{array}$ & Open Space Network & Urban Retrofit \\
\hline Semi Public & $\begin{array}{l}\text { Public, community } \\
\text { groups/Local Government, } \\
\text { Management institution }\end{array}$ & $\begin{array}{l}\text { Courtyard of public facilities: } \\
\text { education, worship; Parks RT/RW } \\
\text { (if any) }\end{array}$ & $\begin{array}{l}\text { Open Space Network } \\
\text { and Building Layout }\end{array}$ & Urban Retrofit \\
\hline Semi Private & $\begin{array}{l}\text { Private, Individual/Local } \\
\text { government, Private }\end{array}$ & $\begin{array}{l}\text { The front yard of the building on } \\
\text { DAWASJA (Regional Road } \\
\text { Supervision) Min width of 3-4 m }\end{array}$ & Streetscape & $\begin{array}{l}\text { Household, } \\
\text { Commercial }\end{array}$ \\
\hline Private & Private, Individual/Private & $\begin{array}{l}\text { Courtyard of the building (outside } \\
\text { the region Road supervision) }\end{array}$ & Building Layout & $\begin{array}{l}\text { Household, } \\
\text { Commercial }\end{array}$ \\
\hline
\end{tabular}

Table 11. Rain Water Management Method for Open Space in Indonesia

\begin{tabular}{|c|c|c|c|c|}
\hline \multirow{2}{*}{$\begin{array}{c}\text { Rain Water Management in } \\
\text { Indonesia }\end{array}$} & \multirow{2}{*}{$\begin{array}{l}\text { WSUD Primary Function } \\
\text { and Method (* }\end{array}$} & \multicolumn{3}{|c|}{ Open Space Function (Indonesia) } \\
\hline & & Social & Aesthetic & Ecological \\
\hline Rainwater Harvesting & $\begin{array}{l}\text { Rainwater Use } \\
\text { - Rainwater Harvesting: } \\
\text { Cistern, Water Butts }\end{array}$ & & $\begin{array}{l}\text { Landscape design, } \\
\text { Architectural design }\end{array}$ & Water Supply \\
\hline Water Retention & $\begin{array}{l}\text { Treatment } \\
\text { - Bio-retention } \\
\text { - Biotopes } \\
\text { - Gravel or Sand Filter }\end{array}$ & $\begin{array}{l}\text { Recreation spaces, } \\
\text { Urban ecology and } \\
\text { biodiversity }\end{array}$ & $\begin{array}{l}\text { Aesthetic Amenity, } \\
\text { Landscapes design }\end{array}$ & $\begin{array}{l}\text { Water Supply } \\
\text { Water Quality } \\
\text { Water Quantity }\end{array}$ \\
\hline $\begin{array}{l}\text { Water Infiltration and } \\
\text { Detention }\end{array}$ & $\begin{array}{l}\text { Detention and Infiltration } \\
\text { - Rooftop Retention } \\
\text { - Permeable Paving } \\
\text { - Infiltration Zones and } \\
\text { Trenches } \\
\text { - Swales } \\
\text { - Geo-cellular Systems } \\
\text { - Dry Detention Pond } \\
\text { - Wet Detention Pond }\end{array}$ & $\begin{array}{l}\text { Urban ecology and } \\
\text { biodiversity } \\
\text { Car parks and access } \\
\text { ways } \\
\text { Recreational use. }\end{array}$ & $\begin{array}{l}\text { Aesthetic Amenity } \\
\text { Landscapes design }\end{array}$ & $\begin{array}{l}\text { Microclimates } \\
\text { Water Quantity } \\
\text { Water Supply }\end{array}$ \\
\hline \multirow[t]{2}{*}{$\begin{array}{l}\text { Mitigating Flood and } \\
\text { Inundation }\end{array}$} & $\begin{array}{l}\text { Conveyance } \\
\text { 1. Open Storm water Canals/ } \\
\text { Drains }\end{array}$ & Recreation spaces & Landscapes design & Water Quantity \\
\hline & $\begin{array}{l}\text { Evapotranspiration } \\
\text { 2. Active and Passive }\end{array}$ & & Aesthetic amenity & Microclimates \\
\hline
\end{tabular}


Table 12. WSUD Element for Private and Public Open Space in Manado

\begin{tabular}{|c|c|c|c|c|c|c|c|c|}
\hline \multirow[b]{2}{*}{ No. } & \multirow[b]{2}{*}{ Open Space Type } & \multicolumn{7}{|c|}{ Element WSUD } \\
\hline & & $\begin{array}{l}\text { Rainwater } \\
\text { Tanks }\end{array}$ & $\begin{array}{c}\text { Bio } \\
\text { retention } \\
\text { Basins }\end{array}$ & $\begin{array}{c}\text { Bio } \\
\text { retention } \\
\text { Swales }\end{array}$ & $\begin{array}{c}\text { Swales, } \\
\text { Buffer } \\
\text { Strips }\end{array}$ & $\begin{array}{l}\text { Infiltration } \\
\text { system }\end{array}$ & $\begin{array}{c}\text { Porous } \\
\text { Pavement } \\
\text { s } \\
\end{array}$ & $\begin{array}{l}\text { Green } \\
\text { Roofs/ } \\
\text { Garden }\end{array}$ \\
\hline \multirow{4}{*}{$\begin{array}{l}\text { A. } \\
\text { A. } 1\end{array}$} & Flat Land & & & & & & & \\
\hline & Private Open Space & & & & & & & \\
\hline & 1. House, Mix Use & $\mathrm{P}$ & $\mathrm{P}$ & PS & PS & PS & $\mathrm{P}$ & $\mathrm{P}$ \\
\hline & 2. Commercial, Office & $\mathrm{P}$ & $\mathrm{P}$ & PS & PS & PS & $\mathrm{P}$ & $\mathrm{P}$ \\
\hline \multirow[t]{4}{*}{ A. 2} & Public Open Space & & & & & & & \\
\hline & $\begin{array}{l}\text { 1. School Buildings, } \\
\text { Places of Worship, } \\
\text { Government Office }\end{array}$ & NS & $\mathrm{P}$ & $\mathrm{P}$ & $\mathrm{P}$ & $\mathrm{P}$ & $\mathrm{P}$ & NS \\
\hline & $\begin{array}{l}\text { 2. Road's Green Line, } \\
\text { Median, Park, Field }\end{array}$ & NS & NS & $\mathrm{P}$ & $\mathrm{P}$ & $\mathrm{P}$ & PS & NS \\
\hline & 3. River Border area & NS & NS & $\mathrm{P}$ & $\mathrm{P}$ & $\mathrm{P}$ & PS & NS \\
\hline \multirow{4}{*}{$\begin{array}{c}\text { B } \\
\text { B.1 }\end{array}$} & Hills & & & & & & & \\
\hline & Private Open Space & & & & & & & \\
\hline & 1. House & $\mathrm{P}$ & NS & PS & PS & PS & NS & NS \\
\hline & 2. Commercial, Office & $\mathrm{P}$ & NS & PS & PS & PS & NS & NS \\
\hline \multirow[t]{4}{*}{ B.2 } & Public Open Space & & & & & & & \\
\hline & $\begin{array}{l}\text { 1. School Buildings, } \\
\text { Places of Worship, } \\
\text { Government Office }\end{array}$ & NS & NS & PS & PS & PS & NS & NS \\
\hline & $\begin{array}{l}\text { 2. Road's Green Line, } \\
\text { Median, Park, Field }\end{array}$ & NS & NS & PS & PS & PS & NS & NS \\
\hline & 3. River Border area & NS & NS & PS & PS & PS & NS & NS \\
\hline
\end{tabular}

P: Potentially Suitable; PS: Possibly Suitable; NS: Not Suitable

\section{WSUD Approach Strategy on Open Space Develop-} ment

WSUD the Open Space approach should be preceded by establishing a system of urban open space with consideration of the existing typology of open space, open space provision policies green open space, non-green open space and the architecture of the city. Table 10 illustrates that the network of open space in urban settlements can be classified into four zones which have differences in scale its services according to the hierarchy of spaces (home, neighborhood RT-RW, Village) and function of open space. Furthermore, in each zone can be determined according to the typology of open space usage form (public, private) and decision makers (government, group, individual). Based on the function of open space and typology of existing open space then determined are two types of technical development WSUD the type Urban Retrofit in public and semipublic zone, and the type of Household and Commercial for private and semi-private zones.

To integrate rainwater management policy in Indonesia on open space with the analytical method approach WSUD functions and methods according to the function of open space needs to be done (Table 11). According to WSUD method development for urban retrofit, commercial and household type, there are seven elements (Table 12) can be used in variety open space type (private or public) with specific site physical (flat or hills).

\section{CONCLUSION}

Applying the concept of sustainable water management WSUD in residential areas, starting with a look at the characteristics of settlements, nature, buildings, infrastructures and utility, as well as residents, then look at the characteristics of the open space, the quality of green open spaces and non-green open space. The first analysis done on slopes, building density, land use and open space network to determine the appropriate location of the study sample. From the analysis in the evaluation and recommends methods and WSUD element corresponding to the location of the study sample, and linking with the policies and existing spatial regulations in Indonesia. Further analysis directed to the Ranotana village as the location of the study sample. Analysis of building density pattern, the pattern of open space, and the river banks, resulting WSUD concept of Open Space Network (Public, Semi Public); Building Lay Out; Streetscape which a recommendation on the development of green infrastructure space of urban settlements in Manado city. 


\section{REFERENCES}

Erwin, H. (2012). Green Space Analysis Based On Oxygen Demands Using the EO-1 ALI (Earth Observer-1 Advanced Land Imager) in Manado City. Info BPK Manado, 2(1), pp. 41-54.

Lensun, M. \& Sipriana, T. (2013). Water pollution level of Tondano River at Ternate Baru Village, Manado. Jurnal Budidaya Perairan, 1(2), pp. 43-48.

Lokita, A. D. (2011). Adaptasi Konsep Water Sensitive Urban Design (WSUD) di Kawasan Cagar Budaya Kota Lama Semarang. Jurnal Perencanaan Wilayah dan Kota, 22(1), pp. 65-80.

Moniaga, I. M. \& Esli, D. T. (2015). Pengembangan RTH Kota Berbasis Infrastruktur Hijau dan Tata Ruang (Studi Kasus: Kota Manado). Prosiding Temu Ilmiah IPLBI. pp. A027-A032

Putra, R. L. (2016). Evaluasi Penggunaan Lahan Sempadan Sungai Sario di Kota Manado. Skripsi Program Studi Perencanaan Wilayah dan Kota, Fakultas Teknik Universitas Sam Ratulangi.

Sompie, B. F. \& Robert, J. M. (2012). Optimasi Penanggulangan Bencana Banjir Di Kota Manado Dengan Metode AHP (analytical hierarchy process). Journal Ilmiah MEDIA ENGINEERING, 2(4), pp. 232-237.

Tarima, G. C. et al. (2016). Analisis kualitas air Sungai Sario Kecamatan Sario Manado Sulawesi Utara. Journal Ilmiah Sains, 16(1), pp. 1923.
Taringan, A. et al. (2013). Quality of Study of Domestic Wastewater in Rivers Passing Through Manado City Based on Organic and Inorganic Materials. Journal Pesisir dan Laut Tropis, 1(1), pp. 55-62.

Stormwater Committee. (2006). Urban Stormwater: Best Practice Environmental Management Guidelines.

Warouw, F. et al. (2016). Pendekatan Konsep Water Sensitive Urban Design dalam Penataan Ruang Permukiman di Kota Manado. Laporan Tahunan Penelitian Unggulan Perguruan Tinggi. Universitas Sam Ratulangi

Kementrian PU. Buku Panduan Program Pengembangan Kota Hijau (P2KH): Panduan Pelaksanaan 2011.

Per Men PU No. 5 Tahun 2008 tentang Pedoman Penyediaan dan Pemanfaatan Ruang Terbuka Hijau di Kawasan Perkotaan.

Per Men PU No. 12 Tahun 2009 tentang Pedoman Penyediaan dan Pemanfaatan Ruang Terbuka Non Hijau di Wilayah Kota/Kawasan Perkotaan.

Per Men PU No. 12 Tahun 2014 tentang Sistem Drainase Perkotaan.

UU No. 26 Tahun 2007 tentang Penataan Ruang.

UU No. 1 Tahun 2011 tentang Perumahan dan Kawasan Permukiman.

PP No. 38 Tahun 2011 tentang Sungai.

PP No.37 Tahun 2012 tentang Pengelolaan DAS.

UU No.7 Tahun2004 tentang Sumber Daya Air. 